\title{
3,3'-Diethylthiatricarbocyanine Iodide: A Highly Sensitive Chiroptical Reporter of DNA Helicity and Sequence
}

\author{
Jung Kyu Choi ${ }^{1}$, Alessandro D’Urso ${ }^{1,2}$, Mitch Trauernicht ${ }^{2}$, Murtaza Shabbir-Hussain ${ }^{1}$, \\ Andrea E. Holmes ${ }^{2}$ and Milan Balaz ${ }^{1, *}$ \\ 1 Department of Chemistry, University of Wyoming, Laramie, WY 82071, USA; \\ E-Mails: jchoi4@uwyo.edu (J.K.C.); adurso@unict.it (A.D.); mshabbir@uwyo.edu (M.S.-H.) \\ 2 Doane College, 1014 Boswell, Crete, NE 68333, USA; \\ E-Mails: mitchell.trauernicht@doane.edu (M.T.); andrea.holmes@doane.edu (A.E.H.) \\ * Author to whom correspondence should be addressed; E-Mail: mbalaz@uwyo.edu; \\ Tel.: +1-307-766-4330; Fax: +1-307-766-2807.
}

Received: 21 October 2011; in revised form: 2 November 2011 / Accepted: 7 November 2011 / Published: 16 November 2011

\begin{abstract}
Using UV-vis absorption and circular dichroism (CD) spectroscopies, we explored the binding interactions of 3,3'-diethylthiatricarbocyanine iodide (Cy7) with polynucleotides of different sequences and helicity. CD showed to be a very diagnostic tool giving different spectroscopic chiroptical signatures for all explored DNA sequences upon Cy7 binding. Cy7 was able to spectroscopically discriminate between the right handed B-DNA of poly $(\mathrm{dG}-\mathrm{dC})_{2}$ and its left handed Z-DNA counterpart induced by spermine or Co(III)hexamine via nearly opposite induced circular dichroic signal.
\end{abstract}

Keywords: Cy7 cyanine dye; left-handed Z-DNA; circular dichroism; DNA recognition; sensing

\section{Introduction}

Cyanine dyes represent an important class of chromophores due to their favorable optical properties, such as high extinction coefficients and fluorescence [1]. Their highly conjugated structure results in a small HOMO-LUMO gap and red shifted absorbance and fluorescence [2,3]. Cyanines cover a wide 
span of applications ranging from fluorescent biomedical imaging, labeling, and non-linear optics to light harvesting and optical storage [4-8].

Cyanines are achiral and thus circular dichroism (CD) silent in the absence of a chiral template like DNA. Binding of the achiral dyes to the chiral DNA helix can result in an induced circular dichroism (ICD) in the absorption spectrum of the dye (500-900 nm). An ICD signal can rise from two distinct phenomena, (a) chiral twisting of the dye in the DNA groove; or (b) an exciton coupling between two chirally oriented dyes. Since cyanines absorb in the visible region whereas nucleic acids absorb in the UV region $(<300 \mathrm{~nm})$, the ICD signal is free of overlaps and very diagnostic of a dye binding mode. $\mathrm{Cy} 3$ and $\mathrm{Cy} 5$ cyanine dyes have previously been reported to bind to alternating adenine-thymine oligo and polynucleotides. Cy5 assembles as parallel helical dimers in the minor groove, and exciton coupled circular dichroism (ECCD) originates from the interaction between the adjacent cyanine dimers (dimer-dimer coupling) [9-13]. However, binding of $\mathrm{Cy} 5$ (Cy3 was not studied) to poly $(\mathrm{dG}-\mathrm{dC})_{2}$ did not yield an ICD signal in the cyanine absorption region. The absence of an ICD was explained by the ineffective, non-coupled orientation of Cy5 upon DNA binding [13]. 3,3'-Diethylthiatricarbocyanine iodide (Cy7, Chart 1) contains a conjugated bridge of seven methines and has a more red shifted absorption than Cy5 $\left(\Delta \lambda_{\max } \sim 100 \mathrm{~nm}\right)$ with an absorption maxima in the NIR region (650 to $800 \mathrm{~nm}$ ). The extended conjugated system makes $\mathbf{C y 7}$ dye more photolabile than its shorter counterparts, and long-term exposure to visible light must be avoided. Herein we report the chiroptical signature of $\mathbf{C y} \mathbf{7}$ binding with polynucleotides having different sequences and helical twists.

Chart 1. Structure of Cy3, Cy5, and Cy7.

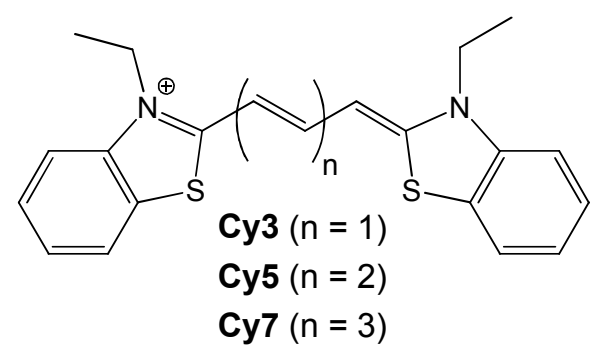

The spectroscopic recognition of DNA helicity is important but challenging [14-18]. The biological relevance of Z-DNA has been demonstrated by the discovery of transcription factors that selectively bind to Z-DNA, and thus have a direct impact on gene expression [19-22]. Z-DNA is left handed and is higher in energy than the canonical right-handed B-DNA [23,24] Thus far, porphyrins [16,18,25-28] helicines [15], and tris(phenanthroline)metal-complexes [29-31] have been used as in vitro Z-DNA probes. No in vivo molecular probes have been reported so far. In order to explore the DNA binding of Cy7, we have selected three polynucleotide sequences allowing us to access four DNA duplexes that differ in nucleobase sequence and helicity: (i) the B-form of poly $(\mathrm{dA}-\mathrm{dT})_{2}$; (ii) the B-form of poly(dC).poly(dG); (iii) and (iv) the B- and Z-forms of poly $(\mathrm{dG}-\mathrm{dC})_{2}$. 


\section{Results and Discussion}

\section{1. $U V$-vis Spectroscopy of the B-forms of poly $(d A-d T)_{2}$, poly $(d C)$.poly $(d G)$, and poly $(d G-d C)_{2}$}

The UV-vis absorption spectrum of $\mathbf{C y} 7$ in the absence of DNA showed a characteristic profile with two major bands at $755 \mathrm{~nm}$ (strong) and $650 \mathrm{~nm}$ (weak). Absorption spectra show that very diverse structural and electronic mechanisms exist when $\mathbf{C y 7}$ is bound to different forms of DNA (Figure 1). Titration of $\mathbf{C y} 7$ into a solution of alternating adenine-thymine polynucleotide poly $(\mathrm{dA}-\mathrm{dT})_{2}$ resulted in a significant increase of intensity at $650 \mathrm{~nm}$ and $750 \mathrm{~nm}$ which was accompanied by the shift of the absorption maxima to a longer wavelength. The Cy7 $(2 \mu \mathrm{M})$ bound to the adenine-thymine DNA $(50 \mu \mathrm{M})$ showed a red shift from $650 \mathrm{~nm}$ to $670 \mathrm{~nm}(\Delta \lambda=20 \mathrm{~nm}, 80 \%$ hyperchromicity) and from $750 \mathrm{~nm}$ to $760 \mathrm{~nm}(\Delta \lambda=15 \mathrm{~nm}, 100 \%$ hyperchromicity) when compared to the DNA-free unbound dye. Similar absorption behavior was observed for the shorter cyanine dye, Cy5, where changes in absorption behavior were explained as a result of a Cy5 dimer formation [9-12]. On the other hand, addition of $\mathbf{C y 7}(0$ to $2 \mu \mathrm{M})$ to a solution of non-alternating polynucleotide poly(dG).poly(dC) resulted in a decrease (40\% hyperchromicity) of the $750 \mathrm{~nm}$ absorption band and an increase (100\% hyperchromicity) of the $650 \mathrm{~nm}$ band. Both bands exhibited bathochromic shifts, $\Delta \lambda_{650}=20 \mathrm{~nm}$ and $\Delta \lambda_{750}=5 \mathrm{~nm}$. Titration of Cy5 into a poly $(\mathrm{dG}-\mathrm{dC})_{2}$ has previously shown to result in hypochromicity of absorption bands without formation of a cyanine dimer. In our case, however, the increase of $650 \mathrm{~nm}$ absorption band together with a red shift (from 650 to $670 \mathrm{~nm}, \Delta \lambda=20 \mathrm{~nm}, 15 \%$ hypochromicity) suggested the formation of a $\mathbf{C y} 7$ dimer upon DNA binding. The decrease of absorption (45\% hypochromicity) and red shift of $750 \mathrm{~nm}$ band $(\Delta \lambda=20 \mathrm{~nm})$ furnished additional evidence for the $\mathbf{C y} \mathbf{7}$ dimer formation in the presence of poly $(\mathrm{dG}-\mathrm{dC})_{2}$. The changes in UV-vis spectroscopy when $\mathbf{C y} 7$ is bound to different forms of DNA originate from structural differences of Cy7 in the minor groove of three examined polynucleotides. Interestingly, cyanine dyes Cy3 and Cy5 were previously found to bind to poly $(\mathrm{dG}-\mathrm{dC})_{2}$ as monomers while our results suggest the formation of Cy7 dimers in the presence of poly $(\mathrm{dG}-\mathrm{dC})_{2}$.

Figure 1. Absorption data for $\mathbf{C y} 7$ dye alone (black), and in the presence of poly $(\mathrm{dA}-\mathrm{dT})_{2}$ (light green), poly(dG).poly(dC) (green), poly(dG-dC) $)_{2}$ (blue), Co(III)-Z-poly(dG-dC $)_{2}$ (red), and spermine-Z-poly(dG-dC) $)_{2}$ (orange). Conditions: [DNA] $=50 \mu \mathrm{M},[\mathrm{NaCl}]=10 \mathrm{mM}$, $5 \% \mathrm{MeOH}$ in Na-cacodylate buffer ( $1 \mathrm{mM}, \mathrm{pH}=7.0)$.

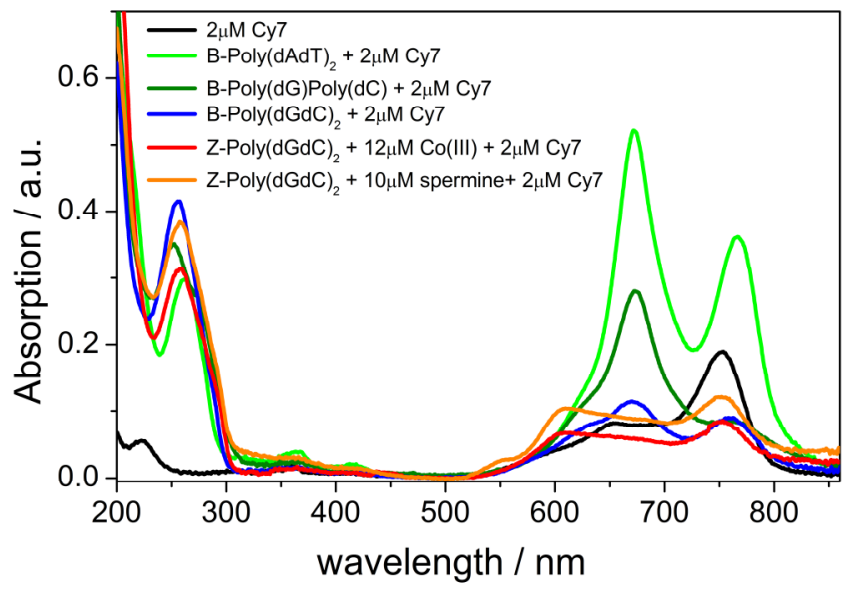




\subsection{Spectroscopy of the B-form of poly $(d A-d T)_{2}$}

Titrations of $\mathbf{C y 7}$ (from $0 \mu \mathrm{M}$ to $1.66 \mu \mathrm{M}, 0.33 \mu \mathrm{M}$ increment) into a solution of poly(dA-dT) ${ }_{2}$ gave rise to a positive $C D$ band at $770 \mathrm{~nm}$ and a negative $C D$ band at $360 \mathrm{~nm}$ (Figure 2). These CD bands originated from the chiral twist of a DNA bound dye. The $770 \mathrm{~nm} \mathrm{CD}$ band coincided with $770 \mathrm{~nm}$ absorption band corresponding to the monomeric form of the dye. Increasing the concentration of $\mathbf{C y} 7$ from $1.66 \mu \mathrm{M}$ to $2.66 \mu \mathrm{M}$ resulted in appearance of a bisignate CD signal with a positive CD band at $686 \mathrm{~nm}$ and negative band at $655 \mathrm{~nm}$ accompanied with an additional increase of ellipticity of the $770 \mathrm{~nm}$ CD band (Inset, Figure 2). This bisignate CD originated from electronic dipole-dipole exciton coupling between two neighboring cyanine dyes. The isosbestic point of the bisignate $\mathrm{CD}$ signal overlapped with the absorption band at $670 \mathrm{~nm}$ and provided additional evidence that the bisignate $\mathrm{CD}$ curve rose from exciton coupling involving $\mathbf{C y} \mathbf{7}$ dimers. The binding of $\mathbf{C y} 7$ did not disturb the secondary structure of DNA which could be seen from the nearly unchanged characteristic DNA region in the $\mathrm{UV}$ region of the $\mathrm{CD}$ spectrum.

Figure 2. CD spectra of $\mathbf{C y} 7$ titrated to poly(dA-dT $)_{2}$. Inset: intensity change of the $\mathrm{CD}$ signals at $770 \mathrm{~nm}$ and $686 \mathrm{~nm}$ as a function of the $\mathbf{C y} 7$ concentration. Conditions: [poly $\left.(\mathrm{dA}-\mathrm{dT})_{2}\right]=50 \mu \mathrm{M},[\mathrm{NaCl}]=10 \mathrm{mM}, 5 \% \mathrm{MeOH}$ in Na-cacodylate buffer $(1 \mathrm{mM}$, $\mathrm{pH}=7.0)$. Titration step: $[\mathbf{C y} 7]=0.33 \mu \mathrm{M}$.

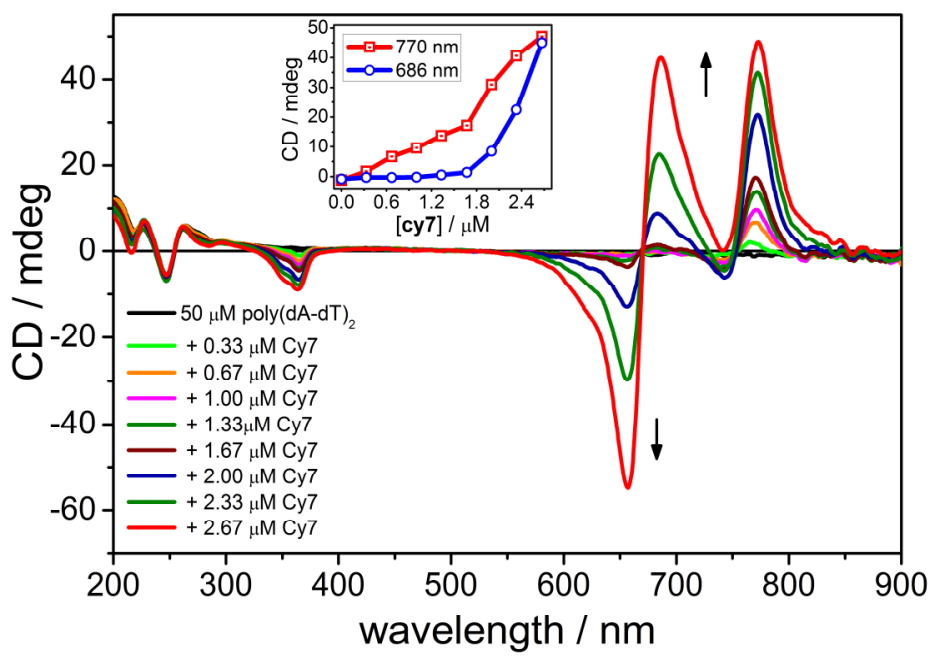

\subsection{Spectroscopy of the B-form of poly $(d C) \cdot \operatorname{poly}(d G)$}

$\mathrm{CD}$ titration of $\mathbf{C y} 7$ to a solution of poly $(\mathrm{dG})$.poly $(\mathrm{dC})$ in $5 \% \mathrm{MeOH} / \mathrm{Na}$-cacodylate buffer revealed a strong bisignate signal with positive Cotton effect at $680 \mathrm{~nm}$ and a negative Cotton effect at 655 with an isosbestic point at $668 \mathrm{~nm}$ (Figure 3). A small negative CD band was also observed at $350 \mathrm{~nm}$. No $\mathrm{CD}$ band was observed at $770 \mathrm{~nm}$ which coincided with a very weak absorption band at that wavelength. It appears that poly $(\mathrm{dG})$.poly $(\mathrm{dC})$ DNA promotes the formation of chiral dimer aggregates even at low concentration of Cy7. Again, virtually no changes have been detected in the CD spectrum below $300 \mathrm{~nm}$. 
Figure 3. CD spectra of $\mathbf{C y} 7$ titrated to poly $(\mathrm{dG})$.poly(dC). Inset: intensity change of the $\mathrm{CD}$ signal as a function of the $\mathbf{C y} 7$ concentration. Conditions: $[\operatorname{poly}(\mathrm{dG}) \cdot \operatorname{poly}(\mathrm{dC})]=50 \mu \mathrm{M}$, $[\mathrm{NaCl}]=10 \mathrm{mM}, 5 \% \mathrm{MeOH}+\mathrm{Na}$-cacodylate buffer $(1 \mathrm{mM}, \mathrm{pH}=7.0)$. Titration step: $[\mathbf{C y} 7]=0.33 \mu \mathrm{M}$.

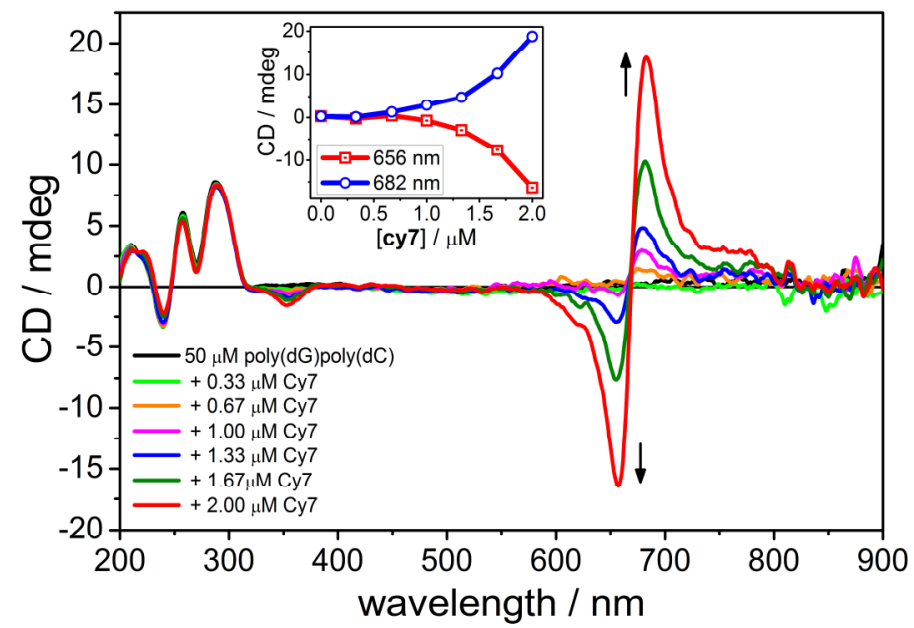

\subsection{Spectroscopy of the B-form of poly $(d C-d G)_{2}$}

Next, we explored the binding of $\mathbf{C y} 7$ with poly $(\mathrm{dG}-\mathrm{dC})_{2}$. Stepwise addition of $\mathbf{C y 7}$ (in $0.33 \mu \mathrm{M}$ addition steps) from $0 \mu \mathrm{M}$ to $1.26 \mu \mathrm{M}$ resulted in an appearance of a positive Cotton effect centered at $690 \mathrm{~nm}$ corresponding to a bound Cy7 monomer (Figure 4). In addition, a very weak negative CD band was observed at $340 \mathrm{~nm}$. Increasing the concentration of $\mathbf{C y 7}$ further (from $1.58 \mu \mathrm{M}$ to $2.21 \mu \mathrm{M}$ ) yielded negative Cotton effects at 850 and $580 \mathrm{~nm}$ and a positive Cotton effect at $620 \mathrm{~nm}$ accompanied with a disappearance of the positive CD band at $690 \mathrm{~nm}$ (Inset, Figure 4). The observed CD spectroscopic changes originated from a rearrangement of the DNA bound $\mathbf{C y} 7$ upon addition of more dye suggesting a different DNA binding mode at low Cy7/DNA ratio $(<1: 50$, i.e., one dye bound for 50 DNA base pairs) and high $\mathbf{C y} 7 / \mathrm{DNA}$ ratio (>1:50).

Figure 4. Titration of $\mathbf{C y} 7$ to poly $(\mathrm{dG}-\mathrm{dC})_{2}$. Titration step: [Cy7] $=0.33 \mu \mathrm{M}$. Inset: intensity change of the $\mathrm{CD}$ signals at $622 \mathrm{~nm}$ and $686 \mathrm{~nm}$ as a function of the $\mathbf{C y 7}$ concentration. Conditions: $\left[\right.$ poly $\left.(\mathrm{dG}-\mathrm{dC})_{2}\right]=50 \mu \mathrm{M},[\mathrm{NaCl}]=10 \mu \mathrm{mM}$, $5 \% \mathrm{MeOH}+\mathrm{Na}$-cacodylate buffer $(1 \mathrm{mM}, \mathrm{pH}=7.0)$.

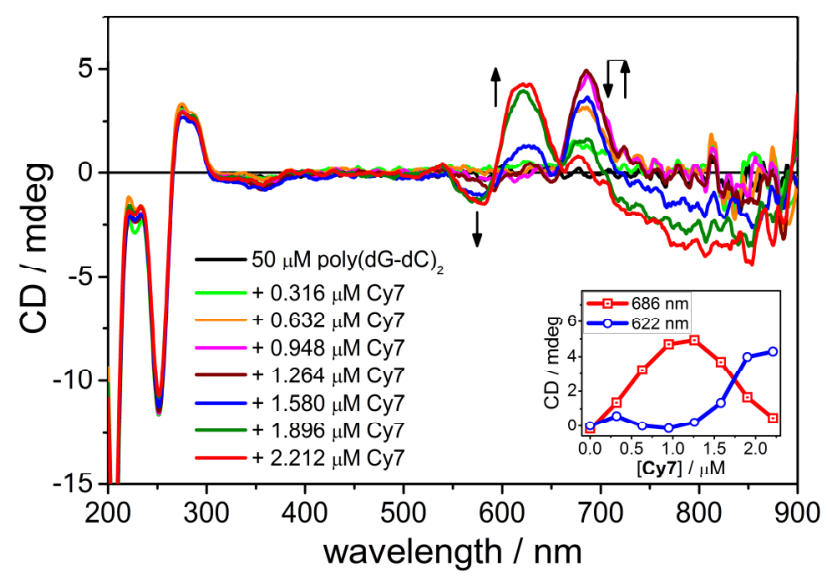


Since the ICD signal was weak in comparison to $\mathbf{C y 7}$ binding with poly(dA-dT) $)_{2}$ or poly $(\mathrm{dG})$.poly $(\mathrm{dC})$ when using $0.33 \mu \mathrm{M}$ increments, we decided to try larger additions $(2 \mu \mathrm{M})$ to enhance the ICD signal. As can be seen in Figure 5, the first two additions of $\mathbf{C y} 7(2$ and $4 \mu \mathrm{M})$ to poly $(\mathrm{dG}-\mathrm{dC})_{2}$ gave rise to a positive Cotton effect at $680 \mathrm{~nm}$ and a negative Cotton effect at $560 \mathrm{~nm}$. Further addition of $\mathbf{C y 7}$ yielded an additional positive $\mathrm{CD}$ band at $640 \mathrm{~nm}$, a small positive CD band at $535 \mathrm{~nm}$ and a broad negative CD band at $850 \mathrm{~nm}$ (Figure 4). It is worth noting that the previously reported shorter cyanine Cy5 dye did not yield an ICD signal when bound to poly $(\mathrm{dG}-\mathrm{dC})_{2}[13]$.

Figure 5. CD spectra of $\mathbf{C y} 7$ titrated to poly $(\mathrm{dG}-\mathrm{dC})_{2}$. Inset: intensity change of the $\mathrm{CD}$ signal as a function of the $\mathbf{C y} 7$ concentration. Titration step: $[\mathbf{C y} 7]=2.0 \mu \mathrm{M}$. Conditions: $\left[\right.$ poly $\left.(\mathrm{dG}-\mathrm{dC})_{2}\right]=50 \mu \mathrm{M},[\mathrm{NaCl}]=10 \mathrm{mM}, 5 \% \mathrm{MeOH}+$ Na-cacodylate buffer $(1 \mathrm{mM}$, $\mathrm{pH}=7.0)$.

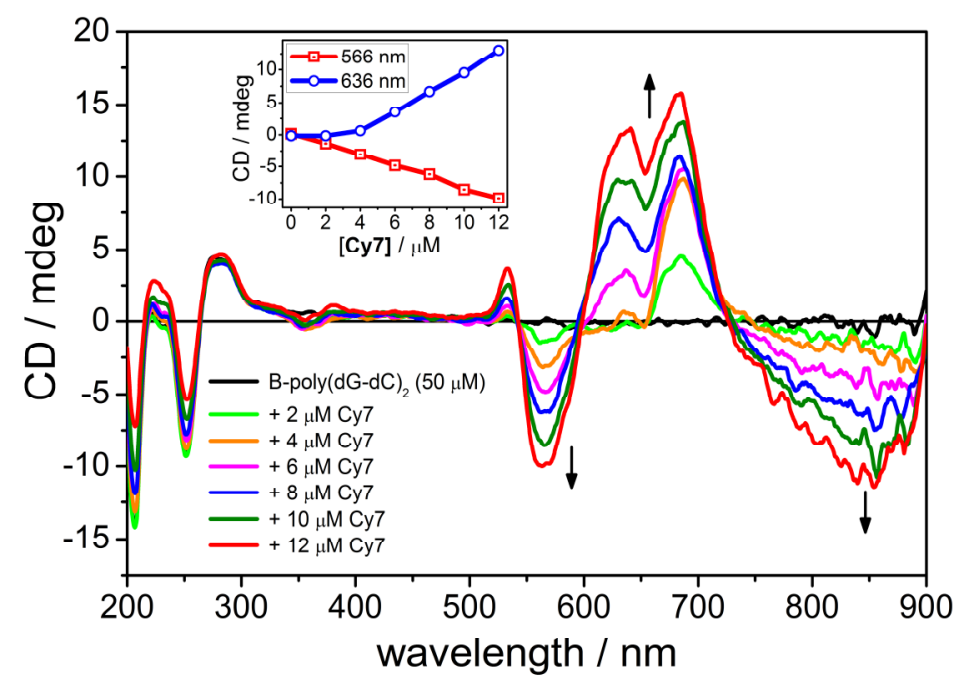

\section{5. $U V$-vis and CD Spectroscopies of the Z-form of poly $(d C-G)_{2}$}

We used poly $(\mathrm{dG}-\mathrm{dC})_{2}$ as a tunable B- to Z-DNA scaffold to access DNA sequences having identical nucleotide composition but different helicity [25]. The fully protonated tetraamine spermine $\left(\mathrm{H}_{3} \mathrm{~N}^{+}-\left(\mathrm{CH}_{2}\right)_{3}{ }^{-} \mathrm{NH}_{2}-\left(\mathrm{CH}_{2}\right)_{4}{ }^{-}{ }^{+} \mathrm{NH}_{2}-\left(\mathrm{CH}_{2}\right)_{3}{ }^{-}{ }^{+} \mathrm{NH}_{3}\right)$ and cobalt(III) hexaamine were employed as micromolar inducers of the Z-DNA conformation [32]. Spermine-Z-DNA was induced at $60{ }^{\circ} \mathrm{C}$ using $10 \mu \mathrm{M}$ spermine, then slowly cooled to RT ( $\left.{ }^{\circ} \mathrm{C} / \mathrm{min}\right)$ while Co(III)-Z-form was induced with $12 \mu \mathrm{M}$ at room temperature [33]. We used two different Z-DNA inducers to investigate the effect of the inducer as an integral part of the Z-DNA structure upon cyanine binding. Successful formation of Z-DNA was confirmed by CD spectroscopy where the spectral region below $300 \mathrm{~nm}$ revealed a spectral signature characteristic of left-handed Z-DNA, i.e., negative CD bands at $290 \mathrm{~nm}$ and $200 \mathrm{~nm}$ and a positive $C D$ band at $260 \mathrm{~nm}$. Since we employed different amounts of Z-DNA inducers $(10 \mu \mathrm{M}$ of spermine ${ }^{4+} v s .12 \mu \mathrm{M}$ of $\left.\mathrm{Co}\left(\mathrm{NH}_{3}\right)_{6}{ }^{3+}\right)$ the final Z-DNA solutions differed in ionic strengths.

Stepwise addition of $\mathbf{C y} 7(0 \mu \mathrm{M}$ to $10 \mu \mathrm{M}, 2.0 \mu \mathrm{M}$ step) to a solution of Co(III) induced Z-form of poly $(\mathrm{dG}-\mathrm{dC})_{2}$ had a distinct effect on the Cy7 UV-vis absorption profile (Figure 1). A $50 \%$ decrease of absorbance at $750 \mathrm{~nm}$ without a wavelength shift has been observed. The $650 \mathrm{~nm}$ band exhibited $20 \%$ hypochromicity and $50 \mathrm{~nm}$ blue shift to $600 \mathrm{~nm}$. Titration of Cy7 to a spermine induced Z-form 
yielded a similar spectroscopic signature, i.e., a 35\% hypochromicity of the $750 \mathrm{~nm}$ band and $20 \%$ hyperchromicity of $650 \mathrm{~nm}$ band accompanied with a $50 \mathrm{~nm}$ blue shift. Addition of $\mathbf{C y 7}$ to the spermine induced Z-poly $(\mathrm{dG}-\mathrm{dC})_{2}$ gave rise to an ICD signal at 500-800 nm with two negative Cotton effects at $645 \mathrm{~nm}$ and $570 \mathrm{~nm}$ and a positive Cotton effect at $605 \mathrm{~nm}$ (Figure 6). The addition of Cy7 to spermine Z-DNA caused significant conformational changes of DNA. As seen in Figure 6, the negative CD band at $290 \mathrm{~nm}$ decreased dramatically upon $\mathbf{C y} 7$ addition. No such change was observed with Co(III) induced Z-DNA (Figure S2), suggesting a lower conformational stability of spermine induced Z-DNA probably caused by a binding competition between spermine and Cy7 in the DNA minor groove.

Figure 6. $\mathrm{CD}$ spectra of $\mathbf{C y} 7$ titrated to spermine induced Z-poly(dG-dC) $)_{2}$. Inset: intensity change of the $\mathrm{CD}$ signal as a function of the $\mathbf{C y} \mathbf{7}$ concentration. Conditions: $\left[\mathrm{Z}\right.$-poly $\left.(\mathrm{dG}-\mathrm{dC})_{2}\right]=50 \mu \mathrm{M}, \quad[$ spermine $]=10 \mu \mathrm{M}, \quad[\mathrm{NaCl}]=10 \mu \mathrm{mM}$, $5 \% \mathrm{MeOH}+\mathrm{Na}$-cacodylate buffer $(1 \mathrm{mM}, \mathrm{pH}=7.0)$. Titration step: [Cy7] $=2.0 \mu \mathrm{M}$.

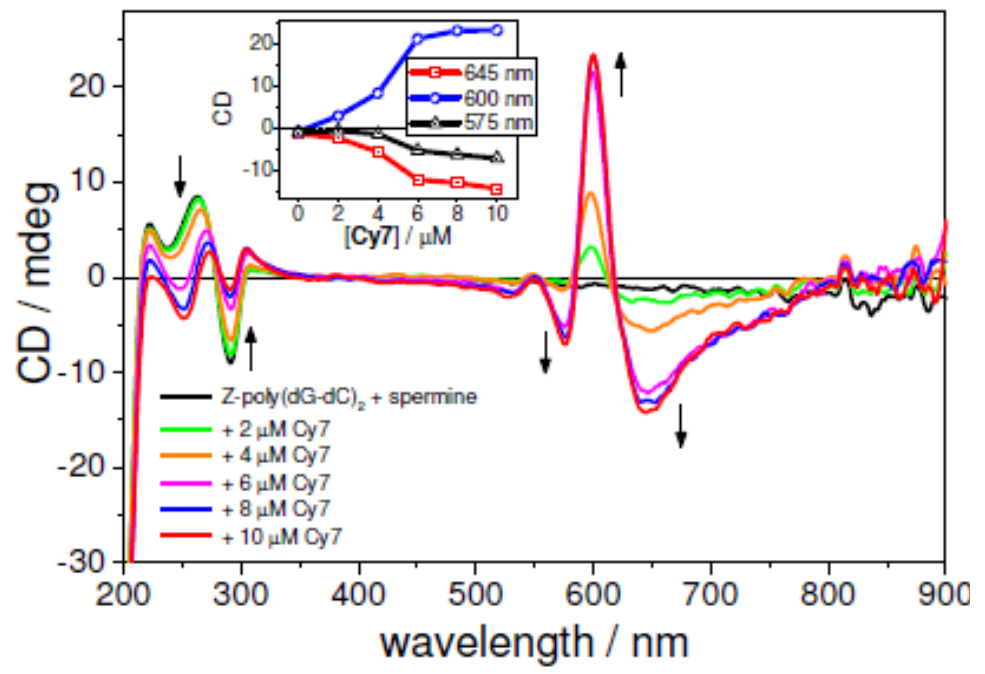

The addition of $\mathbf{C y} 7$ to spermine induced left-handed forms of poly $(\mathrm{dG}-\mathrm{dC})_{2}$ yielded ICD spectra in the visible region with nearly opposite $\mathrm{CD}$ signatures when compared to the $\mathrm{B}$-form of poly $(\mathrm{dG}-\mathrm{dC})_{2}$ (Figure 7). The origin of the nearly opposite CD signals was due to the dye's opposite chiral orientation when bound to the two different DNA helical backbone. This opposite characteristic of Cy7 was clearly seen when the ICD signal of $\mathbf{C y} 7$ bound to B-poly(dG-dC) 2 (Figure 7, blue curve) was compared to ICD signal of the $\mathbf{C y} 7$ bound to Z-form of poly $(\mathrm{dG}-\mathrm{dC})_{2}$ induced by spermine (Figure 7, red curve) and by $\mathrm{Co}\left(\mathrm{NH}_{3}\right)_{6}{ }^{3+}$ (ESI, Figure S3). Therefore, $\mathbf{C y} 7$ allowed for the visualization of DNA structure in the visible spectral range which is far from any possible spectral overlap with indigenous chromophores. 
Figure 7. $\mathrm{CD}$ spectra comparison of $\mathbf{C y} 7$ bound to poly $(\mathrm{dG}-\mathrm{dC})_{2}$ (blue) and spermine induced Z-poly (dG-dC) $)_{2}$ (red). Inset: intensity change of the $C D$ signal at $645 \mathrm{~nm}$ as a function of the $\mathbf{C y} 7$ concentration. Conditions: [DNA] $=50 \mu \mathrm{M}$, [spermine] $=10 \mu \mathrm{M}$, $[\mathrm{NaCl}]=10 \mathrm{mM}, 5 \% \mathrm{MeOH}+\mathrm{Na}$-cacodylate buffer $(1 \mathrm{mM}, \mathrm{pH}=7.0)$. Titration step: $[\mathbf{C y} 7]=2.0 \mu \mathrm{M}$.

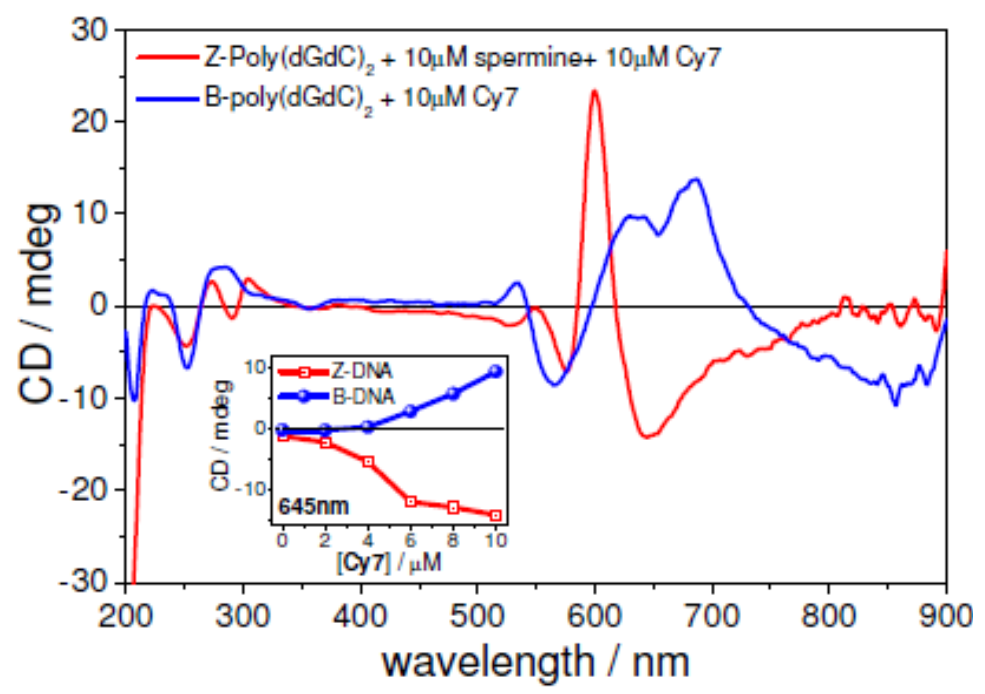

\section{Experimental Section}

3,3'-Diethylthiatricarbocyanine iodide Cy7 (3-Ethyl-2-[7-(3-ethyl-2-benzothiazolinylidene)-1,3,5heptatrienyl]benzothiazolium iodide, DiSC2(7)) was purchased from Sigma-Aldrich. Water was obtained from a Milli-Q system with a resistivity of $18.2 \mathrm{M} \Omega \cdot \mathrm{cm}$. DNA samples were dissolved in a sodium cacodylate buffer ( $1 \mathrm{mM}, \mathrm{pH} 7.0)$, annealed at $80{ }^{\circ} \mathrm{C}$ for $20 \mathrm{~min}$, cooled at $1{ }^{\circ} \mathrm{C} / \mathrm{min}$, and kept at $4{ }^{\circ} \mathrm{C}$. The concentration of the DNA stock solutions was quantified by UV-vis spectroscopy and is reported per base pair. The $\mathbf{C y} 7$ stock solution $(c=0.5 \mathrm{mM})$ was prepared in methanol, and the concentration was determined by UV-vis spectroscopy using the extinction coefficient $\varepsilon=2.5 \times 10^{5} \mathrm{M}^{-1} \cdot \mathrm{cm}^{-1}$ at $758 \mathrm{~nm}[9,33]$.

CD spectra were recorded at $20{ }^{\circ} \mathrm{C}$ using a Jasco J-815 spectropolarimeter equipped with a single position Peltier temperature control system using following conditions: scanning speed $50 \mathrm{~nm} / \mathrm{min}$, data pitch $0.5 \mathrm{~nm}$, DIT $2 \mathrm{~s}$, and bandwidth $1 \mathrm{~nm}$. UV-vis absorption spectra were collected at $20{ }^{\circ} \mathrm{C}$ using a Jasco V-600 UV-vis double beam spectrophotometer equipped with a single position Peltier temperature control system. To minimize the $\mathbf{C y} 7$ photobleaching, all titrations have been performed under reduced light and each CD spectrum was performed as a single scan. A quartz cuvette with a $1 \mathrm{~cm}$ path length was used for all $\mathrm{CD}$ and $\mathrm{UV}$-vis experiments.

\section{Conclusions}

CD spectroscopy was employed to explore the chiroptical behavior of cyanine dye $\mathbf{C y} 7$ in the presence of DNA sequences having different sequences and helical twists. UV-vis absorption spectra reflected very different structural and electronic characteristics of Cy7 when bound to different DNA forms. Cy7 assembles onto poly $(\mathrm{dG}-\mathrm{dC})_{2}$ with a very distinct chiroptical signature, unlike its shorter cyanine counterparts $\mathrm{Cy} 3$ and $\mathrm{Cy} 5$. We showed that $\mathbf{C y} 7$ can spectroscopically discriminate between 
polynucleotides having different sequences using ICD signals in the visible spectroscopic region. $\mathbf{C y 7}$ also recognized and chiroptically distinguished right-handed B-DNA and left handed Z-DNA forms of poly $(\mathrm{dG}-\mathrm{dC})_{2}$ via a very diagnostic induced circular dichroism signal between 500-900 nm.

\section{Acknowledgments}

This research was supported in part by the University of Wyoming Start-Up Fund (M.B.); the NIH, Grant Nos. P20 RR016474 (M.B.) and P20 RR016469 (A.E.H.) from the INBRE Programs of the National Center for Research Resources; the NSF-EPSCoR-EPS-1004094 and the NSF CHE-0747949 (A.E.H.). A.D'U. thanks the 22th PhD program of the University of Catania.

\section{References}

1. Brooker, L.G.S.; Sprague, R.H.; Smyth, C.P.; Lewis, G.L. Color and constitution I Halochromism of anhydronium bases related to the cyanine dyes. J. Am. Chem. Soc. 1940, 62, 1116-1125.

2. Byers, G.W.; Gross, S.; Henrichs, P.M. Direct and sensitized photooxidation of cyanine dyes. Photochem. Photobiol. 1976, 23, 37-43.

3. Yang, S.J.; Tian, H.; Xiao, H.M.; Shang, X.H.; Gong, X.D.; Yao, S.D.; Chen, K.C. Photodegradation of cyanine and merocyanine dyes. Dyes Pigments 2001, 49, 93-101.

4. Mishra, A.; Behera, R.K.; Behera, P.K.; Mishra, B.K.; Behera, G.B. Cyanines during the 1990s: A review. Chem. Rev. 2000, 100, 1973-2011.

5. Mustroph, H.; Stollenwerk, M.; Bressau, V. Current developments in optical data storage with organic dyes. Angew. Chem. Int. Ed. 2006, 45, 2016-2035.

6. Gomez-Hens, A.; Aguilar-Caballos, M.P. Long-wavelength fluorophores: New trends in their analytical use. TrAC Trends Anal. Chem. 2004, 23, 127-136.

7. Webster, S.; Fu, J.; Padilha, L.A.; Przhonska, O.V.; Hagan, D.J.; Van Stryland, E.W.; Bondar, M.V.; Slominsky, Y.L.; Kachkovski, A.D. Comparison of nonlinear absorption in three similar dyes: Polymethine, squaraine and tetraone. Chem. Phys. 2008, 348, 143-151.

8. Flanagan, J.H.; Khan, S.H.; Menchen, S.; Soper, S.A.; Hammer, R.P. Functionalized tricarbocyanine dyes as near-infrared fluorescent probes for biomolecules. Bioconjugate Chem. 1997, 8, 751-756.

9. Garoff, R.A.; Litzinger, E.A.; Connor, R.E.; Fishman, I.; Armitage, B.A. Helical aggregation of cyanine dyes on DNA templates: Effect of dye structure on formation of homo- and heteroaggregates. Langmuir 2002, 18, 6330-6337.

10. Hannah, K.C.; Armitage, B.A. DNA-templated assembly of helical cyanine dye aggregates: A supramolecular chain polymerization. Acc. Chem. Res. 2004, 37, 845-853.

11. Wang, M.M.; Silva, G.L.; Armitage, B.A. DNA-templated formation of a helical cyanine dye J-aggregate. J. Am. Chem. Soc. 2000, 122, 9977-9986.

12. Hannah, K.C.; Gil, R.R.; Armitage, B.A. H-1 NMR and optical spectroscopic investigation of the sequence-dependent dimerization of a symmetrical cyanine dye in the DNA minor groove. Biochemistry 2005, 44, 15924-15929.

13. Seifert, J.L.; Connor, R.E.; Kushon, S.A.; Wang, M.; Armitage, B.A. Spontaneous assembly of helical cyanine dye aggregates on DNA nanotemplates. J. Am. Chem. Soc. 1999, 121, 2987-2995. 
14. Barton, J.K.; Basile, L.A.; Danishefsky, A.; Alexandrescu, A. Chiral probes for the handedness of DNA helices-enantiomers of tris(4,7-diphenylphenanthroline)ruthenium(Ii). Proc. Natl. Acad. Sci. USA 1984, 81, 1961-1965.

15. Xu, Y.; Zhang, Y.X.; Sugiyama, H.; Umano, T.; Osuga, H.; Tanaka, K. (P)-Helicenes displays chiral selection in binding to Z-DNA. J. Am. Chem. Soc. 2004, 126, 6566-6567.

16. Balaz, M.; de Napoli, M.; Holmes, A.E.; Mammana, A.; Nakanishi, K.; Berova, N.; Purrello, R. A Cationic zinc porphyrin as a chiroptical sensor for Z-DNA. Angew. Chem. Int. Ed. 2005, 44, 4006-4009.

17. Seo, Y.J.; Kim, B.H. Probing the B-to-Z-DNA duplex transition using terminally stacking ethynyl pyrene-modified adenosine and uridine bases. Chem. Commun. 2006, 150-152.

18. Balaz, M.; Li, B.C.; Steinkguger, J.D.; Ellestad, G.A.; Nakanishi, K.; Berova, N. Porphyrins conjugated to DNA as CD reporters of the salt-induced B to Z-DNA transition. Org. Biomol. Chem. 2006, 4, 1865-1867.

19. Kim, Y.-G.; Lowenhaupt, K.; Maas, S.; Herbert, A.; Schwartz, T.; Rich, A. The Zab domain of the human RNA editing enzyme ADAR1 recognizes Z-DNA when surrounded by B-DNA. J. Biol. Chem. 2000, 275, 26828-26833.

20. Herbert, A.; Rich, A. The role of binding domains for dsRNA and Z-DNA in the in vivo editing of minimal substrates by ADAR1. Proc. Natl. Acad. Sci. USA 2001, 98, 12132-12137.

21. Kim, Y.-G.; Lowenhaupt, K.; Oh, D.-B.; Kim, K.K.; Rich, A. Evidence that vaccinia virulence faktor E3L binds to Z-DNA in vivo-Implications for development of a therapy for poxvirus infection. Proc. Natl. Acad. Sci. USA 2004, 101, 1514-1518.

22. Champ, P.C.; Maurice, S.; Vargason, J.M.; Camp, T.; Ho, P.S. Distributions of Z-DNA and nuclear factor I in human chromosome 22: A model for coupled transcriptional regulation. Nucleic Acids Res. 2004, 32, 6501-6510.

23. Rich, A.; Zhang, S. Z-DNA: The long road to biological function. Nat. Rev. Genet. 2003, 4, 566-572.

24. Herbert, A.; Rich, A. Left-handed Z-DNA: Structure and function. Genetica 1999, 106, 37-47.

25. D’Urso, A.; Mammana, A.; Balaz, M.; Holmes, A.E.; Berova, N.; Lauceri, R.; Purrello, R. Interactions of a tetraanionic porphyrin with DNA: From a Z-DNA sensor to a versatile supramolecular device. J. Am. Chem. Soc. 2009, 131, 2046-2047.

26. D’Urso, A.; Kyu Choi, J.; Shabbir-Hussain, M.; Ngwa, F.N.; Lambousis, M.I.; Purrello, R.; Balaz, M. Recognition of left-handed Z-DNA of short unmodified oligonucleotides under physiological ionic strength conditions. Biochem. Biophys. Res. Commun. 2010, 397, 329-332.

27. Choi, J.K.; Sargsyan, G.; Shabbir-Hussain, M.; Holmes, A.E.; Balaz, M. Chiroptical detection of condensed Nickel(II)-Z-DNA in the presence of the B-DNA via porphyrin exciton coupled circular dichroism. J. Phys. Chem. B 2011, 115, 10182-10188.

28. D’Urso, A.; Holmes, A.E.; Berova, N.; Balaz, M.; Purrello, R. Z-DNA recognition in B-Z-B sequences by a cationic zinc porphyrin. Chem. Asian J. 2011, 6, 3104-3109.

29. Chow, C.S.; Barton, J.K. Transition metal complexes as probes of nucleic acids. Methods Enzymol. 1992, 212, 219-242.

30. Barton, J.K.; Lolis, E. Chiral discrimination in the covalent binding of bis(phenanthroline)dichlororuthenium(II) to B-DNA. J. Am. Chem. Soc. 1985, 107, 708-709. 
31. Barton, J.K.; Dannenberg, J.J.; Raphael, A.L. Enantiomeric selectivity in binding tris(phenanthroline)zinc(II) to DNA. J. Am. Chem. Soc. 1982, 104, 4967-4969.

32. Parkinson, A.; Hawken, M.; Hall, M.; Sanders, K.J.; Rodger, A. Amine induced Z-DNA in poly $(\mathrm{dG}-\mathrm{dC})$. poly $(\mathrm{dG}-\mathrm{dC})$ : Circular dichroism and gel electrophoresis study. Phys. Chem. Chem. Phys. 2000, 2, 5469-5478.

33. Sheppard, S.E.; Geddes, A.L. Effect of solvents upon the absorption spectra of dyes. IV. Water as solvent: A common pattern. J. Am. Chem. Soc. 1944, 66, 1995-2002.

(C) 2011 by the authors; licensee MDPI, Basel, Switzerland. This article is an open access article distributed under the terms and conditions of the Creative Commons Attribution license (http://creativecommons.org/licenses/by/3.0/). 